\title{
The impact of globalization on selected aspects of marketing communication in the circular economy
}

\author{
Dominik Jánoš ${ }^{1, *}$ \\ ${ }^{1}$ University of Ss. Cyril and Methodius, Faculty of Mass Media Communication, Department of \\ Marketing Communication, Nám. J. Herdu 2, 91701 Trnava, Slovakia
}

\begin{abstract}
.
Research background: From the world point of view, we are continually struggling with the opinion that economic growth must be connected with the deterioration of the environment and the quality of people's lives. If we talk about environmental policy based on globalization changes, the discussion is more about mitigating the negative impacts of industrial production. Most products are not made in the way they can be reused in production, so the company is not ready to deal with the waste that is accumulated in various legal and illegal landfills. The priority of the circular economy is globally considered as save and efficiency in the use of limited natural resources, constantly streamlining the production of individual products associated with high efficiency and low consumption of lowemission resources. These are the main reasons why it is essential to focus on this area and bring innovative options on how to inform the public about this issue.

The aim of the article: Our paper aims to point out, from the perspective of globalization, how important is the application of individual tools of marketing communication in the circular economy, through which the general public gets acquainted with the application of innovative environmental concepts.
\end{abstract}

Methods: Main research from the dissertation thesis, the results of which we also used in this paper, consisted of more parts - analyses of findings, quantitative research, statistics methods.

Findings and value-added: From a summary of gained findings is possible to prepare a general knowledge model for the mentioned areas.

Keywords: Globalization; Environment; Marketing communication; Circular economy; Consumer

JEL Classification: $F 63 ; F 64 ; F 96$

\footnotetext{
*Corresponding author: dominikjanos16@gmail.com
} 


\section{Introduction}

Recently, the adverse effects of society on the environment have become more visible in our society. From a global perspective, it is influenced by factors such as the growing population, causing an enormous increase in material consumption. Globalization is about the transmission of persons, processes and products from one part of the world to another. This is a process through which material and social phenomena generated in one part of the world become part of the lives of people in other parts of the globe[1]. Jens Bartelson [2] analyses in more detail the concept of globalization since it has undergone significant changes over the last ten years. He considers globalization to be a process of interaction and transfer between existing units, exchange across existing unit boundaries as well as between units and a system, but with an assumption that this system and units remain the same throughout the whole globalization process. Globalization have reduced spatial barriers and asymmetry in development, and poor regions and rural areas may seize the new opportunities to develop their economies [3]. Environmental innovations have a significant effect on eliminating such a human activity and protecting the environment. The results of these innovations cannot be evaluated only by economic parameters because these parameters, to a large extent, modify the reality when being implemented in practice. This issue must be looked at in a broader context, because in addition to the essential functions of environmental protection, it also significantly affects the factor of sustainable development of the company, directly affecting the company's position in a competitive global environment. The circular economy also belongs to the system solving this problem. The marketing communication implemented in this issue aims towards acquainting the general public with the environmental concept of society. The changes that marketing has faced since the 21 st century can be characterized as breaking. These are turbulent and global changes in the external environment in individual companies. The changes mainly concern the increase in the number of products and product lines, brands, shortening the life cycle of products, market segmentation, increasing consumer demands and also the complex process of how to get focused attention. Marketing must respond to these changes by changing the orientation, but also by changing focus. Focusing on maximizing consumer value and the need to bring supply more effectively towards the consumer can be considered as crucial. These activities also lead to a change in marketing communication in companies.

Currently, we also consider the term of the circular economy to be extremely popular, even in terms of globalization changes. It means working in a modern way with available resources, efficient ways to use energy and employees in individual processes. We observe this issue to become one of the main topics of various conferences aimed at improving the environment. One of the tools for successful implementation in practice is a marketing communication. This tool is one of the essential elements ensuring the realization of the conditions of the circular economy. All stakeholders must comply with established obligations and rules. The circular economy, with the support of marketing communication, can make all processes more effective and as a result, it is also possible to achieve an improvement in the environment.

\subsection{Consumer as the part of innovations}

In a diverse business environment with the gradual creation of a global market, there are fundamental forces such as the demands of customers, the growth of supply and services and the related competition in individual markets. An essential factor for the enterprise's survival is the need for greater attention for actions and tools that would prevent adverse effects and risks in business activity. [4] With the development of technology, innovation is a means to cope with a given change. It is crucial if an organization wants to keep up and have a 
competitive advantage and pay adequate attention to innovation. Continually coming up with new ideas, developing a company innovation policy and focusing on development trends are crucial activities. Innovative processes are also included, as they need to be improved as well. Strong organizations that care about their development in the field of innovation usually have the first positions in the market itself. Innovative activities are aimed at increasing the performance of a particular business entity. They are connected with the preparation and sale of the original idea. In practice, we characterize these activities as sudden innovations. The main goal of innovation activities is the consumer and he has to be involved in the innovation process, as Trommsdorff and Steinhoff claim: "The active integration of the customer into the innovation process requires an approach where market needs are systematically acquired and evaluated in order to reduce product failures. The integration of the customer into the process of acquiring new product ideas is particularly important so that the next phase can be built on that, such as the development of the product up to its launch combined with a targeted marketing strategy." [5]

Many studies focus on describing the relationship between the acceptance of a particular product's innovation and the consumer. At the same time, they relate the consumer and his innovation, as a particular feature of his personality, based on which he accepts innovation or rejects it. Chaod, Reid and Movando have created three models of consumer acceptance of innovation:

- The customer's natural innovation - they compare consumer innovation to an individual personality that allows them to adopt an innovative product without affecting the shopping experience that other consumers have had.

- The domain of specific innovation - acceptance of an innovative product by consumers only in a specific area of interest, does not apply to all product attributes. However, this model points to the interconnectivity of a specific category of products that have been innovated and a tendency to own them.

- Substitute innovation - emphasizes the importance of having information on innovation spread through the media. Based on it, the consumer can form an opinion about the innovated product without having direct contact with it. It is important what types of information he gets because to buy something - he decides based on this information. [6]

The new economy creates the conditions for a new concept of thinking, based on new knowledge using information and communication technologies. The work of people in companies is specified to particular activities, distributed in the organizational structure and gradually assigned to employees within specific jobs. Like the activities that are characteristic of each organization, the processes are also considered to be a characteristic. "Those who accept innovative thinking as part of their workflow should develop a system of adaptive support measures to help them become more flexible in the market and increase value for their external and internal partners. " [7]

\subsection{Communication aspects in the circular economy}

The task of marketing communication is to inform, share information on the quality, the value of usefulness, use itself. In addition to this role, it is necessary to respond to consumer demands. The essence of communication activities is to influence the shopping behavior of consumers while using communication system tools. As the information society, we identify an era whose characteristic features are information of a quantitative and qualitative nature. Over the past decade, we have encountered several concepts of the information society. In the literature, there are terms such as post-industrial, postmodern, knowledge, in connection with the designation of the information society. The availability of the information database 
contributes to market competitiveness. This new type of human society is mainly related to the use of information and communication technologies. [8]

Marketing communication is significantly influenced by digital media, as it works through a shared virtual space. Even though we no longer consider the Internet as a new technology, but as a networked infrastructure as its availability is understood as a right for people. "Thanks to the trends of the digital age, marketing communication has a wide range of opportunities to spread marketing and communication messages. It is mostly caused by new opportunities providing a boom in mass communication and information technologies, but also due to the effort of marketers to attract attention with new, non-traditional forms of presentation and staging of original advertising and promotional campaigns. (...) The transfer of information brings more economic benefits, more time flexibility and the possibility of getting feedback allows more precise targeting of the marketing product." [9]

The circular economy is a strategy of sustainable development, through which functional and healthy relationships are created between the natural environment and people. It is understood to act as an opponent of a linear system. „The ability of enterprises to maintain a sufficient degree of competitiveness in today's globalized environment requires a consistent management approach and maximum alignment of all organizational activities. "[10] The basic principles of the circular economy are based on the idea that product and material flows be reintroduced into the cycle after use, where they become resources essential to create new products and services. The aim is to limit waste production. Until now, solutions have been based on replacing primary materials with secondary ones. The starting point for this situation was to be recycling. However, we cannot consider this solution to be attractive, as its overall process is considered to be very energy-intensive. In general, we talk about the degradation of materials, which leads to an orientation of demand for raw materials. The circular economy is beyond recycling. Recycling is based on a renewable industrial system that leads to the extinction of waste.[11] We understand recycling as the outer packaging of the circular economy, even though it requires higher energy consumption than the inner packaging of the circular economy creates. From the perspective of globalization is the circular economy, a strategy of long-term sustainable development, through which one can create functional and healthy relations between the natural environment and people. It is understood as an opponent of the linear system. They think about materials the products are made of, the amount of energy used in the production process, the externalities of production or the distribution of products and the options of product disposal.[12]

The circular economy should serve to make better use of the product life cycle while minimizing energy consumption. A characteristic feature of the circular economy is a closed cycle of material and energy flow, considering science, technology, human and natural resources. "By switching to renewable energy sources, the circular model of the economy creates economic, natural and social capital at the macroeconomic level. At the enterprise level, this model, using enterprise innovation, focuses on redefining products and services, designing waste treatment, and minimizing negative impacts. ”[13]

The essence of the circular economy is to use waste as a potential source and fulfill the closed cycle with it. This closed-cycle is generally called a "closed loop". Its principles reach beyond recycling. The essence of the circulation model is to reuse, repair and renovate. By this, it preserves the utility value of individual products, their attributes and materials. "As far as Europe is concerned, the introduction of a closed loop is logical and necessary, especially given the high dependence on imports of raw materials from abroad and the volatile political situation in the world." [14] Based on the estimation, we state that by 2030 this system could save in the European Union up to 1.8 trillion euros a year. "The circular economy refers to the production and consumption of goods through closed-loop material flows that internalize the environmental effects associated with the extraction of raw 
materials and the generation of waste (including pollution). The main goal is to reduce resources, consumption and pollution and waste at every step of the product life cycle." [15]

To implement sustainable marketing management, it is necessary to re-evaluate at the level of the enterprise many existing marketing activities related to customer needs, individual elements of the marketing mix, responsibility. A very significant change is the extension of the return period of investments related to the building of sustainable marketing management, as this concept emphasizes the long-term perspective or continuity in the long term. Marketing communication is an essential and most important factor in the functioning of marketing. The goal of this communication is to gain knowledge about the customer's needs and turn it into a product. Marketing communication must run in two streams, be balanced and ethical. The beginning of this communication is created by starting the marketing management of the company.

\section{Methods}

Research work needs to implement quality data collection and processing. To widen the information database, it is appropriate to carry out marketing research, such as quantitative research. Within the quantitative research, we did a secondary data collection through the study of theoretical sources and materials of various authors, sources of the Slovak Statistical Office, articles in professional journals. Subsequently, the collection of primary data was performed.

In the current situation, not only governments but also the public audience, including individual companies, begin to realize the need to introduce sustainable economic development techniques. As a result, customers demanding safe products for both their health and the environment also require a competitive advantage. Entrepreneurs in Slovakia start currently use the tools of the circular economy and green innovations. The two most significant issues that also shown up in our research are climate change and the economic crisis. The solution to these problems is to make appropriate suggestions and recommendations based on the results of our research.

\section{Results}

The marketing survey took place from January 2020 to April 2020. The research sample consisted of 385 respondents. The survey was focused on the respondents' knowledge of the principles of the circular economy and the guidance of purchasing behavior based on communication tools. The target group of our survey was divided into three age categories, from 18 to 30 years in $24 \%$, the group from 31 to 50 years represented $39 \%$ and the last group aged from 51 to 65 years was represented by $37 \%$. Also, based on this percentage distribution, it is evident that we tried to address all categories in the target group with almost the same share.

We researched whether the respondents from our sample follow the individual communication tools during the shopping process. Interesting fact - up to 162 respondents from the sample could not provide opinion on this question. 119 respondents answered positively and 104 respondents said that communication tools play no role in the purchasing process.

We focused on finding out the knowledge of individual principles of the circular economy among the researched respondents. For us, the most surprising finding was that up to 177 respondents did not know the characteristics of the circular economy at all. 123 respondents know this issue and 85 respondents from the total sample do not know the principle of the circular economy. 
In the article, we present only the most important findings.

Question: Which sources do you use to get information on environmental protection?

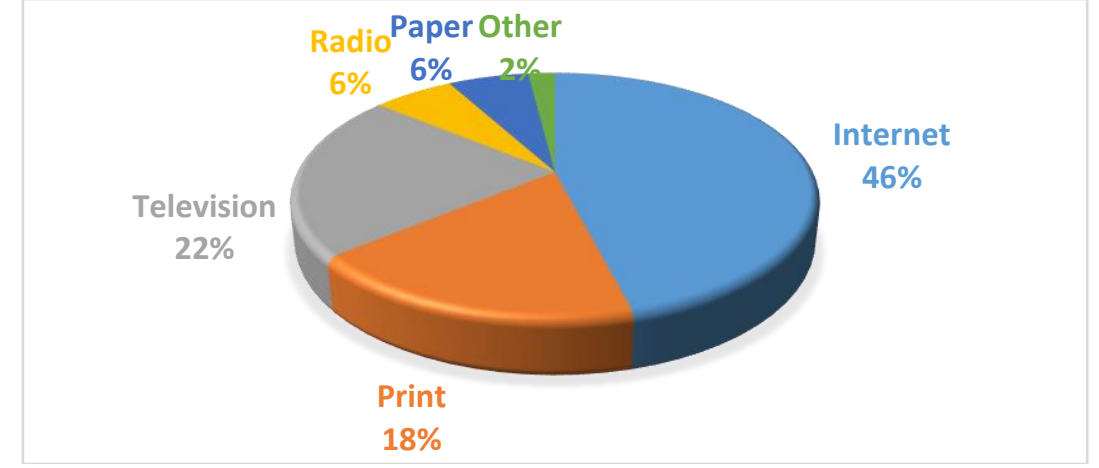

Fig. 1. Information source on the environment protection. Source: Own elaboration.

In this particular question, we evaluated the match of the most frequently occurring answers from the respondents. The results show that most of them, i.e., $46 \%$ of respondents consider the Internet to be the essential source of information in the field of environmental protection.

Question: Does knowledge of the principles of the circular economy influence your purchasing decisions?

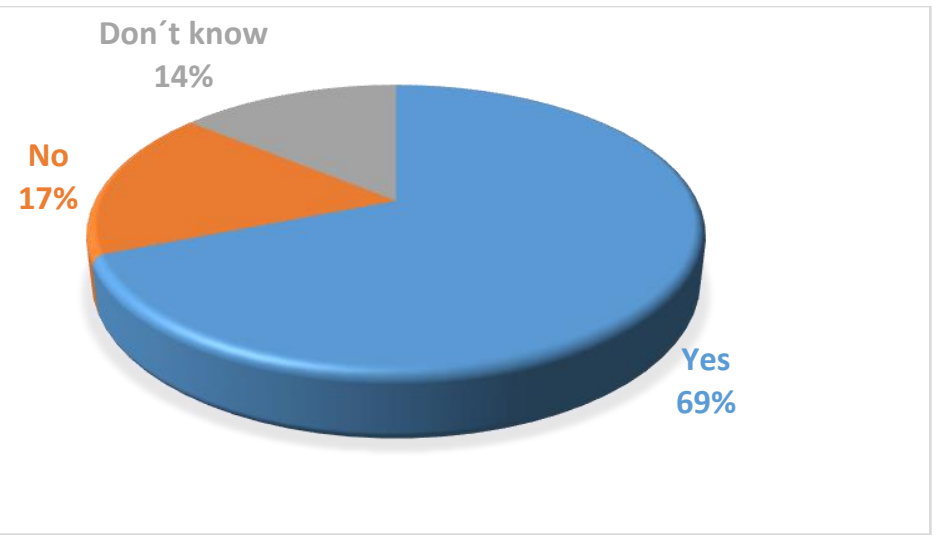

Fig. 1. Knowledge of circular economy principles. Source: Own elaboration.

Based on the results, we conclude that up to $69 \%$ of respondents are influenced by the principles of the circular economy when making purchasing decisions. 
Question: Do you consider product labels to be a valuable source of information influencing your shopping behavior?

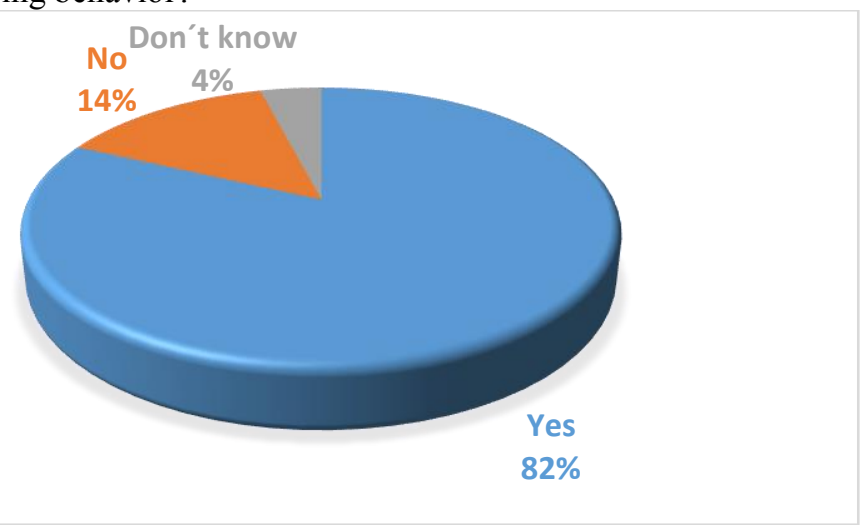

Fig. 3. Labels as the source of information. Source: Own elaboration.

This question was focused on reviewing the information value of labels on products and their subsequent impact on purchasing behavior. The results clearly show that up to $82 \%$ of respondents consider the information value of labels within their shopping behavior.

We consider the effective use of marketing communication tools in innovation processes to be a necessary prerequisite for the proper functioning of a company. Communication tools connect and unify the individual components in the organization and create an essential prerequisite for achieving the set goals. Communication is a targeted tool for evaluating employees, motivating, guiding and communicating with suppliers, consumers and other stakeholders. Every business entity plays an essential role in a specific environment.

\section{Conclusion}

The results suggest that the rate of innovation and technological progress is currently very low throughout the complete globalization process. Innovation is an essential element of the circular economy. When evaluating the specific data obtained, we conclude that the level of awareness of the population is at a relatively low level in the field of eco-innovation and the introduction of the circular economy globally. The need for rapid sharing of information within maintaining a healthy environment can be emphasized. Although the first entities are currently showing up, dealing with this particular issue (e.g., a workshop for disabled people in the east of Slovakia, they produces a new material from textile waste and plastic waste as an experiment, out of this material, they create simple bags.)

If companies want to be successful, they must consider the researched findings. Business entities will achieve the implementation of these conditions through the application of important innovative environmental models. Consideration of the impact of environmental protection will then return in the form of improving the image, creating a competitive advantage, gaining potential customers and increasing various economic indicators.

All companies in Slovakia, from the perspective of globalization processes as well, endeavor to overcome their competition by utilizing all the available means. The applying of innovations also belongs under these available means. Applying innovations ensures companies the option to introduce a unique product to the market or generate a unique value in an already realized product. It represents a tool with which they create a competitive advantage. It is necessary to note that properly selected promotion plays a big role in the introduction of innovations. This factor influences the earliness of introducing an innovation to the market.[16,17] 
The most critical areas for improving the current situation are the area of providing information within the products, improving the communication skills of sales staff and the process of choosing appropriate communication channels for communication.

All relevant findings can be used well in the conditions of the Slovak Republic:

- defining the complex issues occurring in the implementation of the circular economy in practice

- developing a comprehensive view of the introduction of the circular economy in the conditions of the European Union,

- developing a comprehensive view of the implementation of marketing communication tools in the conditions of the European Union,

- increasing consumer awareness of environmental pollution in purchasing decisions and purchasing behavior,

- creating a training methodology for sales staff when selling eco-products,

- proposing a methodological procedure for the implementation of individual tools of marketing communication in the application of the principles of the circular economy.

This paper is an output of the research project supported by the Grant Agency of the Ministry of Education of the Slovak Republic and the Slovak Academy of Sciences (VEGA) No. 1/0078/18 titled Aspects of Marketing Communication in the Management Processes of Circular Economy.

\section{References}

1. Prilleltensky, I. (2012). The what, why, who, and how of globalization: What is psychology to do? Journal of Social Issues, 68(3), 612-629.

2. Bartelson, J. (2000). Three concepts of globalization. International Sociology, 15(2), 180-196.

3. Wei, Y. D., Lin, J., Zhang, L. (2019). E-Commerce, taobao villages and regional development in China. Geographical review, 110(3), 380-405.

4. Labudová, L., Jánošová, D. (2019). Analysis of support and identification of barriers to SMEs in Slovakia and in the Czech republic. Serbian Journal of Management, 14(2), 437-453.

5. Trommsdorff, V., Steinhoff, F. (2009). Marketing inovací. Praha: Nakladatelství CH Beck.

6. Chao, C. W., Reid, M., Mavondo, F. T. (2012). Consumer innovativeness influence on really new product adoption. Australasian Marketing Journal, 20(3), 211-217.

7. Šalgovičová, J. (2019). Vybrané problémy marketingovej komunikácie v kruhovej ekonomike v etape globalizácie. Trnava: UCM.

8. Rajčák, M., Rajčáková, E. (2012). Marketingová komunikácia. Aktuálne trendy metódy - techniky. Trnava: UCM.

9. Rajčák, M. (2013). Marketingová komunikácia v digitálnom veku (vybrané trendy, metódy a techniky). Trnava : UCM.

10. Musova, Z., Musa, H., Ludhova, L. (2018). Environmentally responsible purchasing in Slovakia. Economics \& Sociology, 11(4), 289-305.

11. Sauvé, S., Bernard, S., Sloan, P. (2016). Environmental sciences, sustainable development and circular economy: Alternative concepts for trans-disciplinary research. Environmnental Development, 17, 48-49. 
12. Šalgovičová, J. (2018). The relationships between the circular economy and the quality of life in a globalized society. In T. Kliestik (Ed.), Proceedings of the 18th International Conferecnce Globalization and Its Socio-Economic Consequences (pp. 2781-2788). Žilina: University of Zilina.

13. Cséfalvayová, P., Maleš, I., Luuptáková, M. (2017). Slovensko a cirkulárna ekonomika. Bratislava: Inštitút cirkulárnej ekonomiky.

14. Heymann, J., Earle, A., McNeill, K. (2013). The impact of Labor Policies on the Health of Young Children in the Context of Economic Globalization. Annual Review of Public Health, 34, 355-372.

15. O'Rourke, K. H. (2019). Economic history and contemporary challenges to globalization. Journal of Economic History, 79(2), 356-382.

16. Linsi, L., Mugge, D. K. (2019). Globalization and the growing defects of international economic statistics. Review of International Political Economy, 26(3), 361-383.

17. Šalgovičová, J., Jánoš, D. (2019). Use of Marketing Tools on Selected Aspects of Circular Economy. Průhonice: Professional Publishing. 